Primljen / Received: 7.2.2012.

Ispravljen / Corrected: 13.1.2013.

Prihvaćen / Accepted: 21.3.2013.

Dostupno online / Available online: 10.5.2013.

\section{Dynamic analysis of Dolmabahce masonary clock tower}

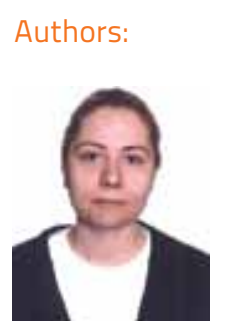

Asena Soyluk, Ph.D.

Gazi University in Ankara, Turkey

Department of Architecture

asenad@gazi.edu.tr

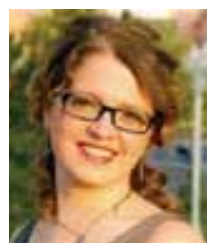

Zeynep Yeşim llerisoy, M.Sc.

Gazi University in Ankara, Turkey

Department of Architecture

zyharmankaya@gazi.edu.tr
Professional paper

\section{Asena Soyluk, Zeynep Yeșim İlerisoy}

\section{Dynamic analysis of Dolmabahce masonary clock tower}

Recent earthquakes around the world have shown that most masonry clock towers are susceptible to structural damage and collapse. An appropriate tower model was erected in order to investigate structural behaviour of a historic masonry watch tower at the Dolmabahce Palace in Istanbul. The initial analysis of self-weight was followed by dynamic analysis, which took into account the influence of deeper soil layers next to tower foundations, and seismic motions registered for soft and stiff soil conditions during the 1999 earthquake in Kocaeli, Turkey.

\author{
Key words: \\ masonry tower, soft soil, stiff soil, dynamic analysis, earthquake response
}

Stručni rad

Asena Soyluk, Zeynep Yeşim Ilerisoy

\section{Dinamička analiza Dolmabahce zidanog tornja sa satom}

Nedavni potresi u svijetu pokazali su kako je većina zidanih tornjeva sa satom podložna konstrukcijskim oštećenjima i urušavanju. Kako bi se istražilo ponašanje konstrukcije povijesnog zidanog tornja sa satom Dolmabahce u Istanbulu, izrađen je model tornja. Početno je analizirano djelovanje vlastite težine nakon čega je provedena dinamička analiza koja je uzela u obzir utjecaj dubljih slojeva tla uz temelje tornja te potresna gibanja zabilježena kod mekanih i čvrstih uvjeta tla prilikom potresa u Kocaeli u Turskoj 1999. godine.

Ključne riječi:

zidani toranj, dinamička analiza, utjecaj potresa, interakcija tla i građevine, potres

Fachbericht

Asena Soyluk, Zeynep Yeșim Ilerisoy

\section{Dynamisches Verhalten des Dolmabahce Uhrturms aus Mauerwerk}

Aktuelle Erdbeben in der Welt haben mehrheitlich gezeigt, dass Uhrtürme aus Mauerwerk möglichen Bauschäden und Einbrüchen ausgesetzt sind. Um das Verhalten der Konstruktion des historischen Uhrturms aus Mauerwerk im Dolmabahce-Palast in Istanbul zu erforschen, ist ein Model des Turmes erstellt worden. Zunächst ist die Einwirkung des Eigengewichts analysiert worden und anschließend ist eine dynamische Analyse durchgeführt worden, in der Einflüsse der tieferen Bodenschichten um die Fundamente des Turmes berücksichtigt worden sind. Dafür sind seismische Aufzeichnungen des Erdbebens in Koceali in der Türkei im Jahre 1999 für weiche und steife Bodentypen eingesetzt worden.

\section{Schlüsselwörter:}

Mauerwerksturm, weicher Boden, steifer Boden, dynamische Analyse, Erdbebenantwort 


\section{Introduction}

Clock towers, which are important meeting points in people's daily life, are monumental buildings connecting past to present with historic values. Towers, giving clues of traditional architecture and being a common heritage of human history, have become symbols of cities. In order to pass on these symbols to future generations, it is of crucial significance to preserve them from collapse and damage. The conservation of historical masonry towers has gained in significance in the world after the sudden collapse of the Civic Tower in Pavia, Italy $[1,2,3]$. Some investigations about such towers, involving both analytical and experimental analyses, are the "Torrazzo" in Cremona [4], the Civic Tower in Vicenza [5], the St. Stefano Bell-tower in Venice [6], and the eighth-century masonry tower called "Torre Sineo" in Alba [7]. However, these studies do not take into account the change of dynamic behaviour of the towers depending on the soil-structure interaction (SSI) for different ground motion recordings of the same earthquake.

Ever since the time of Ottoman Empire, a lot of clock towers in Turkey have been constructed according to the masonry technique involving natural stones. These magnificent structures, built in various styles such as baroque or oriental, differ in body shapes and can thus be cylindrical, quadrilateral, polygonal, intertwined prisms, or structures narrowing by height [8]. It is however known that the strength of historical masonry structures is very low in case of an earthquake action. Turkey, which has a lot of historical structures, is located in one of the most active earthquake zones in the world, and high magnitude earthquakes commonly occur in this region. According to earthquake zoning map which is based on information on geologic structure, plate tectonics, historical seismicity, and earthquake occurrence, Turkey comprises five different seismic zones [9]. There are 62 clock towers in the $1^{\text {st }}$ level seismic zone in Turkey [10]. However, most of these masonry towers suffer serious damage, or even collapse, during these seismic activities. Some recent examples of collapsed towers are Kocaeli Clock Tower and Istanbul Bakırköy Psychiatric Hospital Clock Tower [8].

The dynamic behaviour of masonry towers depends on the intensity of ground shaking, the frequency content of the earthquake wave,

Table 1. Turkish Seismic Code: soil and site classification [8] and the type of underlying soil. Past earthquakes have shown that buildings of similar type, but with different local soil characteristics, are damaged differently, even under the same magnitude of earthquake. In fact, the propagation of seismic waves differs according to properties of soil through which they pass. Recent earthquakes in Ceyhan (27.06.1998, M=6.2), Gölcük (17.08.1999, $M=7.8$ ), and Bingöl (01.05.2003, $M=6.4$ ) in Turkey have revealed that the maximum damage was observed on meadows having soft soil properties, even in cases when they are located far away from the main fault [11]. This situation shows that there is a strong relationship between earthquakes effects and local soil properties. Lutes [12] shows that uncertainty about soil stiffness might cause considerable uncertainty about the frequency content of structural response, and may sometimes modify expected values of the frequency content. It is crucial to understand the dynamic behaviour of masonry towers to improve sustainability, and to preserve or strengthen these historical monumental structures. In this study, the structural behaviour of the tower under its selfweight is investigated initially with the finite element method. Then, to determine the effect of earthquake ground motions, recorded in different soil conditions, on the seismic response of masonry towers, the attention is focused on evaluating seismic response of the masonry clock tower taking sub-soil conditions into account. For this purpose, ground motions recorded at stations with different soil conditions and located at the same distance from the tower are used. The results obtained for different soil types are compared with each other according to the elastic base assumption.

The source document for site classifications is defined in the Specification for Structures to be Built in Disaster Areas, 2007, [9]. The information regarding the basics for site classifications is provided in its commentary. The commentary describes how soil deposits amplify the level of ground shaking relative to the level of bedrock shaking. The amount of ground motion amplification depends on wave-propagation characteristics of the soil, which can be estimated from shear wave velocity measurements. In the Turkish Seismic Code, site classes are defined in terms of the shear wave velocity (Table 1). In this study, stiff and soft soil types corresponding to Z1 and Z4 site classes, respectively, are used.

\begin{tabular}{|c|c|c|c|c|}
\hline $\begin{array}{l}\text { Soil } \\
\text { Group }\end{array}$ & Generic description & $\begin{array}{c}\text { Shear wave } \\
\text { velocity }[\mathrm{m} / \mathrm{sec}]\end{array}$ & Site class & $\begin{array}{l}\text { Soil group and } \\
\text { top layer thickness }\end{array}$ \\
\hline (A) & $\begin{array}{l}\text { 1. Rock (Unweathered Or Stiff) } \\
\text { 2. Very Dense Sand, Gravel } \\
\text { 3. Hard Clay, Silt Clay }\end{array}$ & $\begin{array}{l}>1000 \\
>700 \\
>700\end{array}$ & $\mathrm{Z1}$ & $\begin{array}{l}\text { Group (A), } h \leq 15 \mathrm{~m} \\
\text { Group (B), } h \leq 15 \mathrm{~m}\end{array}$ \\
\hline (B) & $\begin{array}{l}\text { 1. Soft Rock (Weathered) } \\
\text { 2. Dense Sand, Gravel } \\
\text { 3. Very Stiff Clay, Silty Clay }\end{array}$ & $\begin{array}{l}700-1000 \\
400-700 \\
300-700\end{array}$ & $\mathrm{Z2}$ & $\begin{array}{l}\text { Group (B), h> } 15 \mathrm{~m} \\
\text { Group (C), h } \mathrm{h} 15 \mathrm{~m}\end{array}$ \\
\hline (C) & $\begin{array}{l}\text { 1. Highly Weathered Soft Rock } \\
\text { 2. Medium Dense Sand And Gravel } \\
\text { 3. Stiff Clay, Silty Clay }\end{array}$ & $\begin{array}{l}400-700 \\
200-400 \\
200-300\end{array}$ & $\mathrm{Z3}$ & $\begin{array}{l}\text { Group (C), h }=15-50 \mathrm{~m} \\
\text { Group (D), } \mathrm{h} \leq 10 \mathrm{~m}\end{array}$ \\
\hline (D) & $\begin{array}{l}\text { 1. Soft Deep Alluvial Layers } \\
\text { 2. Loose Sand } \\
\text { 3. Soft Clay, Silty Clay }\end{array}$ & $\begin{array}{l}<200 \\
<200 \\
<200\end{array}$ & Z4 & $\begin{array}{l}\text { Group (C), } h>50 m \\
\text { Group (D), } h>10 m\end{array}$ \\
\hline
\end{tabular}


Table 2. Mechanical characteristics of materials

\begin{tabular}{|c|c|c|c|c|}
\hline Material & Model Elements & $\mathrm{E}[\mathrm{GPa}]$ & $\gamma\left[\mathrm{kN} / \mathrm{m}^{3}\right]$ & Poisson's ratio $v$ \\
\hline Limestone & Solid & 8.5 & 21.9 & 0.20 \\
\hline Marble & Solid & 10.0 & 27 & 0.26 \\
\hline
\end{tabular}

\section{Finite element model of the case study}

Actual behaviour of masonry structures is generally highly complicated. Thus, many simplifications are necessary these structures are modelled [13]. For correct definition of the behaviour of the structural system, and deformations and internal forces in the members due to various loads and environmental effects, the basic principles of the finite element modelling can be classified as follows [14]:

- The simplest model most often gives optimum results. Complex models that go beyond the aim and scope of the analysis are unnecessary.

- All structural effects that are required for the analysis should be taken into consideration when determining dimensions of elements contained in the model.

- The model that is created by merely separating a particular part of the overall model is not sufficient to define behaviour of the section or member in question. Models that accurately define boundary conditions and connections are required in order to obtain a detailed behaviour-related information [15].
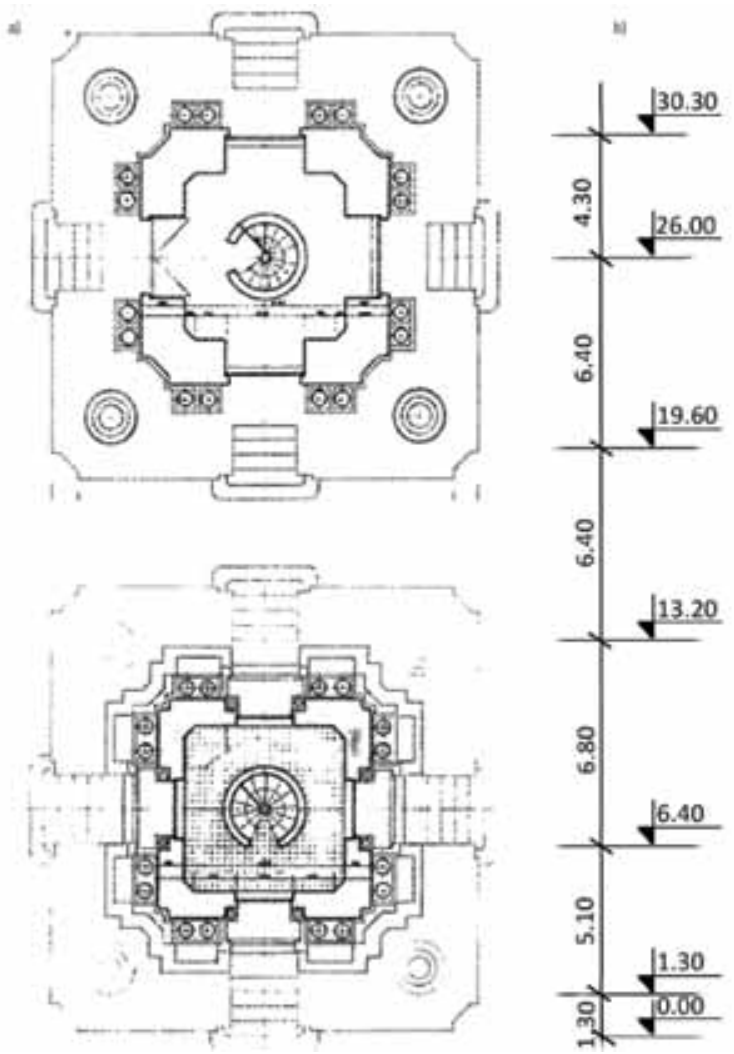

In the light of the above mentioned principles, the Dolmabahce Clock Tower is considered in this paper as case study. This tower is situated outside of the Dolmabahce Palace in Istanbul, and stands in front of its Treasury Gate on a square along the European waterfront of Bosphorus, next to Dolmabahce Mosque. The tower was constructed by Sarkis Balyan, a renowned Turkish architect of Armenian descent, and designed in the Ottoman Neo-Baroque style between 1890 and 1895 [16].

\section{1. Structural properties of Tower and superstructure modeling}

The four-sided, four-story tower with a square plan is embedded in the $12 \times 12 \mathrm{~m}$ marble platform. The floor dimensions of the clock tower are as follows: $8.50 \times 8.50 \mathrm{~m}$ for the base, $7.40 \times 7.40 \mathrm{~m}$ for the first and second floors, and $6.00 \times 5.00 \mathrm{~m}$ for the third floor (Figure1a) [17]. Its height from the base level is $30.4 \mathrm{~m}$ [17]. The bearing system of the Dolmabahce Clock Tower, which was built as a masonry structure using limestone, comprises solid walls that are drawn inside, and columns in each facade of first two floors (Figures 1b-1c).
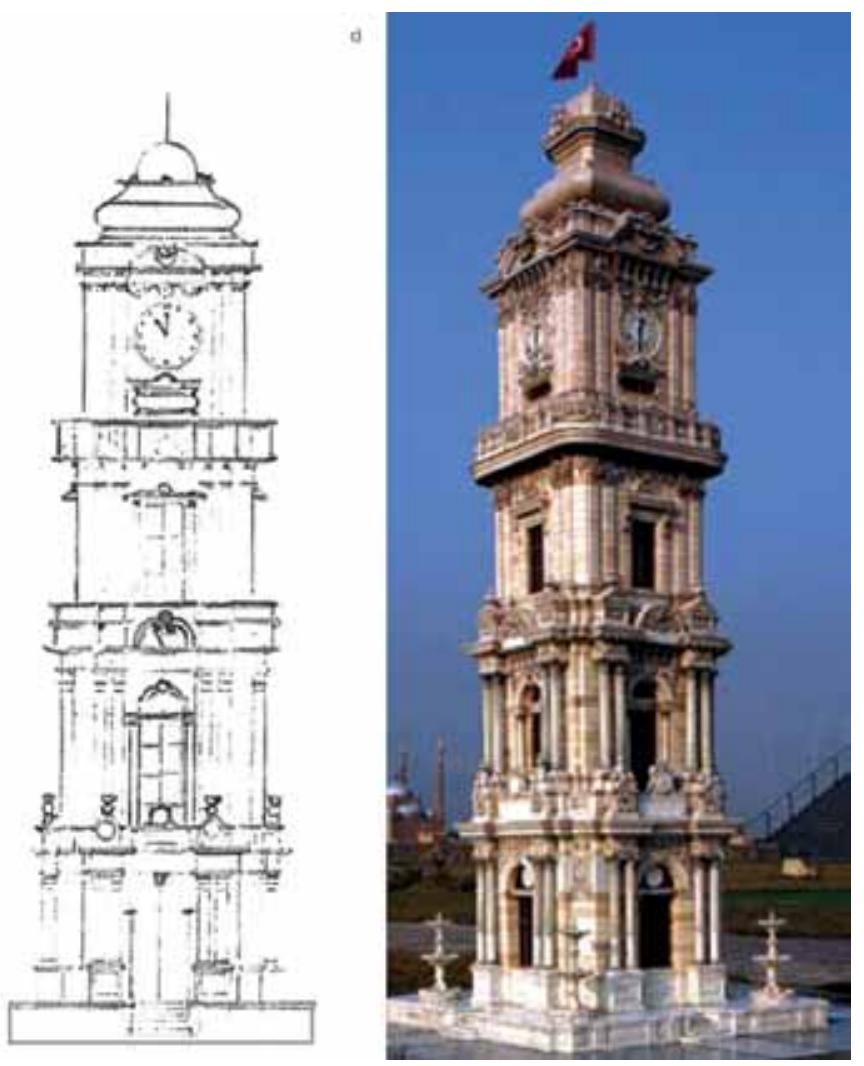

Figure 1. Dolmabahce Clock Tower: a) floor plans; b) front view; c) present situation 
The Dolmabahce Clock Tower, which is elastically supported in the base by 496 spring elements, is modelled with 5845 nodal points and 3862 solid elements by the SAP 2000 computer program. Mechanical properties of the construction materials are important and should accurately be defined for structural analysis of historical structures. In this study, there is not enough information about material properties of this masonry clock tower. Therefore; properties of the limestone and marble are taken from similar studies [18-20] (Table 2). In the models, the linear elastic material behaviour is assumed and the stiffness degradation is neglected.

\subsection{Subsoil conditions and modelling}

For site investigation, one borehole was executed in order to obtain detailed information about the soil profile at the Dolmabahce Clock Tower. Observations revealed that there is an artificial fill, consisting of remains of some old structures and limestone blocks, between the bedrock and the existing ground level. Soil profiles of foundations of the underlying structure, according to the data from the boring log, are shown in Figure 2 [21].

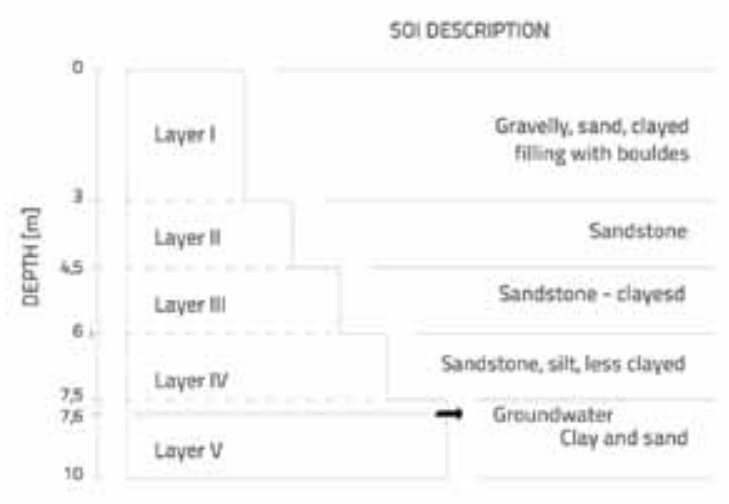

Figure 2. Boring log of the Dolmabahce Clock Tower [10]

Filled soil, $5 \mathrm{~m}$ in approximate thickness, is located in the top profile. This soil is an aggregate made of of sandygravelly-clayey filling with boulders. This is followed by the sandstone-silt (less clayed) profiles down to the depth of $10 \mathrm{~m}$. Groundwater level is at approximately 7,6 $\mathrm{m}$. The local soil class of the Dolmabahce Clock Tower is defined as Z3 (Table 1), and the vertical bearing coefficient of the filled soil profile in the zone of foundations is calculated as $113,5\left[\mathrm{kN} / \mathrm{m}^{3}\right][21]$.

Winkler's Hypothesis is used in this study as the primary subgrade model in soil structure interaction (SSI) application. It is an approximation of the soil reaction to a distributed loading, such that it takes into account the major contributor to the soil resistance, i.e. the soil stiffness. The hypothesis suggests that the soil develops a resistance to loading in form of discrete and independent elements, thus disregarding the shearing that exists between the soil layers [22]. Winkler's approximation is presented in Figure 3.
The force-displacement characteristics of a SSI problem can be summarized as follows:

- The force applied by the superstructure on the substructure $q(x, y, z, t)$, which can be defined in terms of location and time, depending on whether the force is static or dynamic in nature. (In 2-D static loading: $q(x, y)$ )

- The reaction of soil to load imposed on it by the superstructure $p(x, y, z, t)$. (In $2-D$ static loading $p(x, y)$ )

- The settlement within the supporting soil in order to generate the necessary reaction $w(x, y, z, t)$.

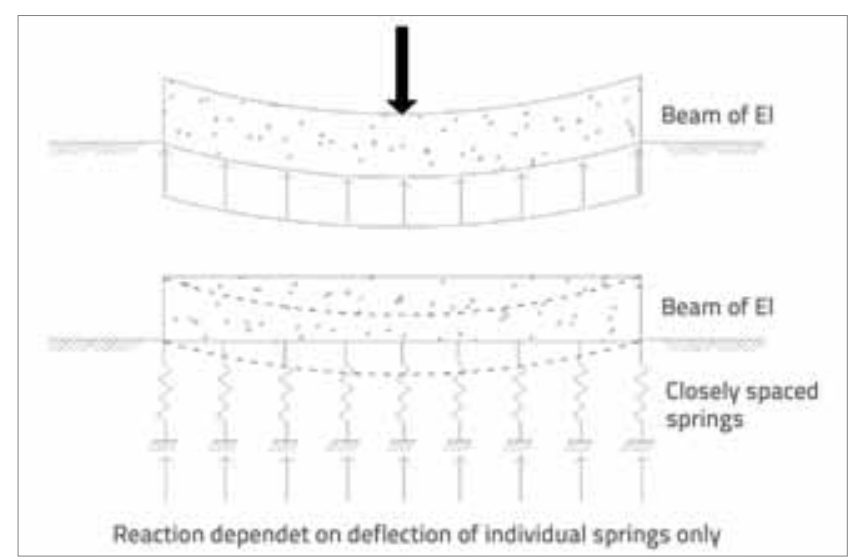

Figure 3. Winkler's approximation of soil resistance for a slab on grade [22]

In the traditional approach to SSI problem solving, the subgrade reaction, $p(x, y, z, t)$, is considered as an external force whose magnitude must be assumed or postulated mathematically in some manner at the beginning of the analysis. Also, in the traditional approach, the subgrade reaction is considered as independent and discrete reactions. Because $p(x, y)$ has such a crucial role as an input parameter in simplified analyses used in practice, it is very useful to define a new subgrade stiffness parameter, $k(x, y)$, that is called the coefficient of subgrade reaction and is defined as:

$k(x, y)=\frac{p(x, y)}{w(x, y)}$

Winkler's Hypothesis is a single-parameter subgrade model because only one in Parameter; $k$, is necessary to define its behaviour. The load-displacement characteristics of soil are idealized by the use of spring elements in Winkler's method [23]. In this study, attempts are made to determine the effect of the application of the single-parameter subgrade model on historical masonry structural responses. While the $U x, U y$ translational and $R z$ rotational degrees of freedoms at the foundation nodal points are fixed, $U z$ vertical translational degree of freedom is supported by point springs assigned to nodal points for the soil-structure interaction modelling [24]. After geotechnical investigations, it was assumed for numerical calculations that the foundation area has an elastic sub-grade modulus of $113,5\left[\mathrm{kN} / \mathrm{m}^{3}\right]$. 


\section{Structural assessment and dynamic behaviour of Dolmabahce masonry clock tower}

The structural behaviour of masonry structures differs from that of reinforced concrete structures. Historical masonry structures have low ductility and, due to their stiff and brittle structural components, they are usually severely damaged during earthquakes. The main reason for the damage is the lack of ductility that prevents the structure to withstand displacements and distortions caused by severe earthquakes [25]. To be able to understand the real structural behaviour of the tower, the model is first operated with regard to self-weight of the structure, and then the earthquake loads are considered.

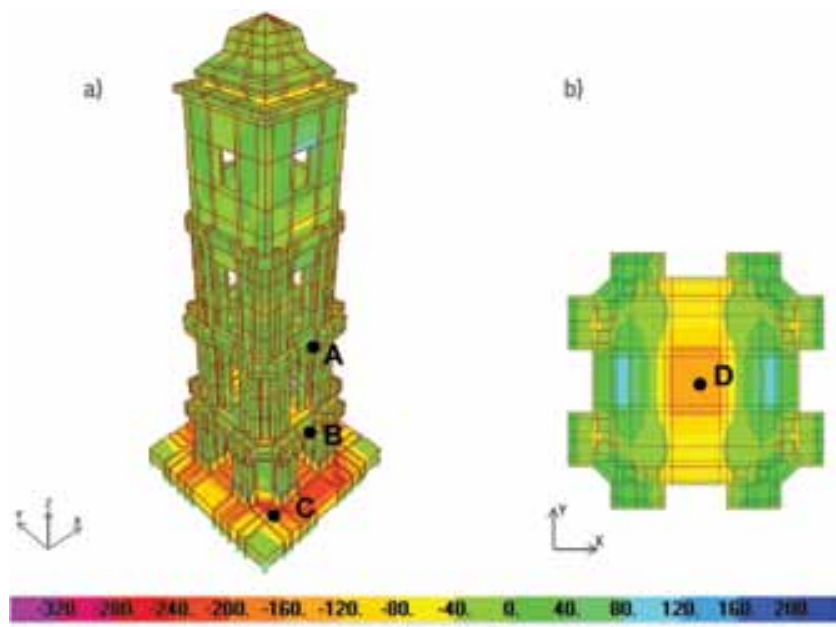

Figure 4. Stress contours of under the construction self-weight: a) clock tower; b) first floor slab under self-weight

Stresses under the self-weight are shown in Figure $4 \mathrm{a}$. Compressive stresses occur mostly at the marble base plate, and the largest value is $0.325 \mathrm{MPa}$. Tensile stresses also occur in this type of slender towers because of their height. Tensile stresses are observed at the hollows, projections and slabs
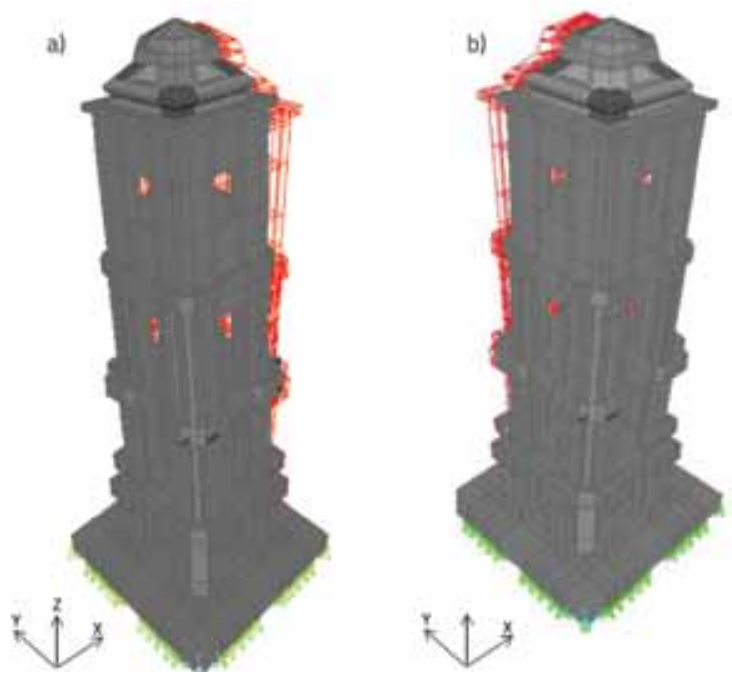

Figure 5. Clock Tower's a) Mode 1; b) Mode 2; c) Mode 3; d) Mode 4
(Figure 4b). The largest value of the tensile stress is observed under the first floor slab, where it amounts to $0.194 \mathrm{MPa}$.

Modes showing free vibration of structural systems are important for interpreting behaviour of structural systems under earthquake motions. Therefore, modal analysis results are considered so that the dynamic behaviour of the clock tower can be investigated (Figure 5).

As can be observed, the first mode is the translational motion in the $x$ direction, the second mode is the translational motion in the $y$ direction, the third mode reflects torsional motion of the clock tower, and the forth mode corresponds to the bending mode. Periods for the first four modes are $0.75 \mathrm{sec}$, $0.75 \mathrm{sec}, 0.19 \mathrm{sec}$ and $0.15 \mathrm{sec}$, respectively.

If stresses under self-weight and the modal behaviour of the clock tower are considered, it can be concluded that the tower does not contain any risk with regard to its overall stability. Time history analyses were used to obtain information about the real behaviour of this tower under a particular earthquake. Time-history analyses are not used as often as some other conventional methods, like the response spectrum method, because of the lack of knowledge and availability of actual ground motion data. However, the time history analysis can be considered as the most realistic one if compared to other methods [26].

In this method, structural responses are evaluated by subjecting the structure to a recorded earthquake. An important step in the application of time history analysis is the selection of a representative earthquake. In this study, linear time-history analyses are carried out using real ground motions recorded at stations with different soil conditions, located at the same distance from the tower. The 17 August, 1999 Kocaeli earthquake, of the magnitude 7.51, is used as a real earthquake motion in this paper. Properties of stations from which the data were obtained are given in Table 3, and earthquake acceleration recordings for two different soil types are shown in Figure 6.

While the Bursa recording (BR) was made at hard soil (Rock), the Fatih recording (FR) was made at a very soft soil during the Kocaeli earthquake (Figure 6). It is worth noting that the vertical component
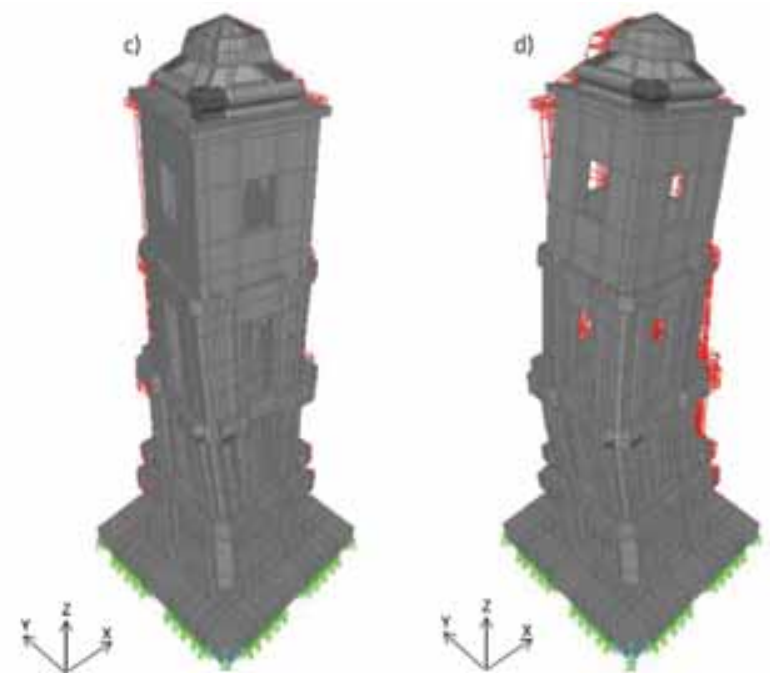
Table 3. Recorded peak ground accelerations [28]

\begin{tabular}{|c|c|c|c|c|c|}
\hline \multirow{2}{*}{ Station } & \multirow{2}{*}{ Distance from rupture $[\mathrm{km}]$} & \multirow{2}{*}{ Site class } & \multicolumn{3}{|c|}{ Peak acceleration $[\mathrm{g}]$} \\
\cline { 4 - 6 } & & & N-S & E-W & 0.05 \\
\hline Bursa & 67 & Stiff soil & 0.05 & 0.03 \\
\hline Fatih & 65 & Soft soil & 0.18 & 0.16 & 0.13 \\
\hline
\end{tabular}
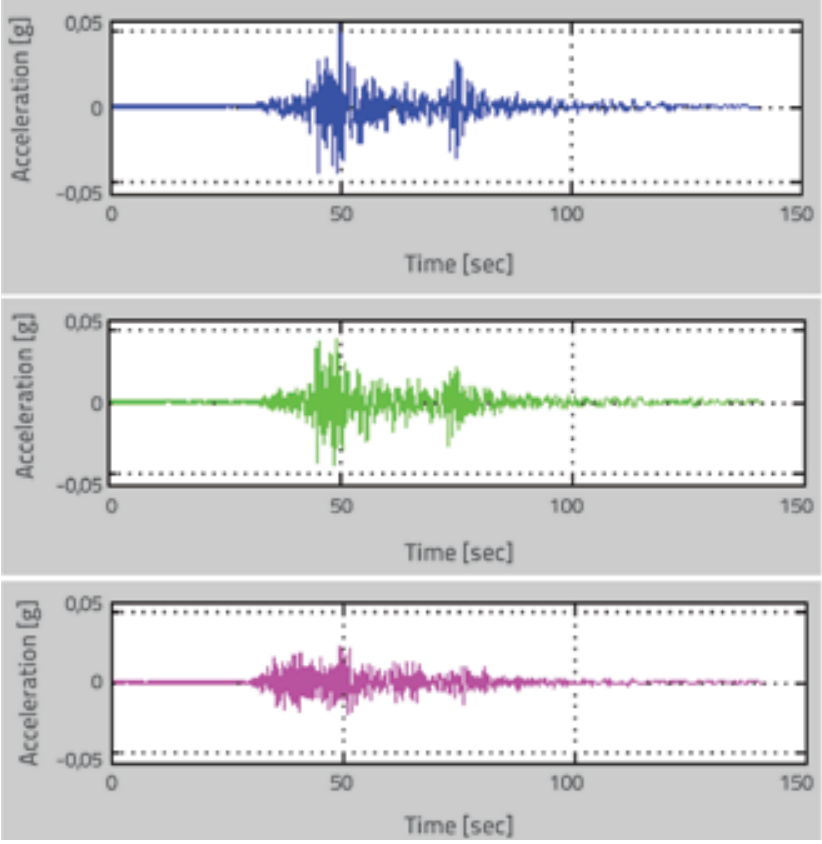
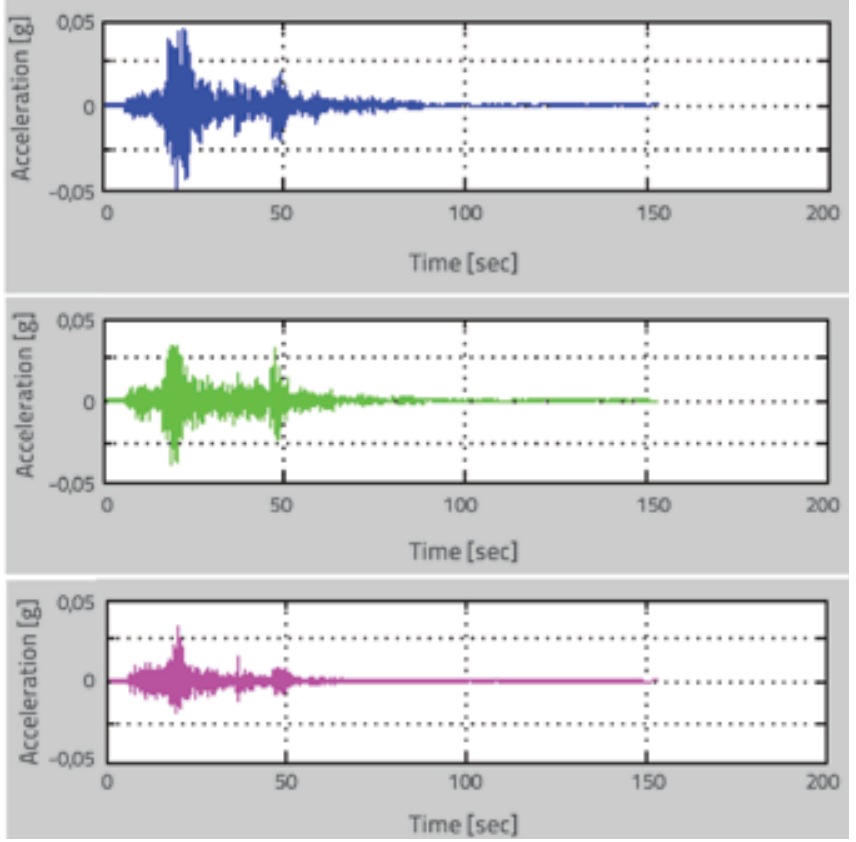

Figure 6. Kocaeli earthquake: Bursa (stiff soil), left; Fatih (soft soil), right [27, 29]

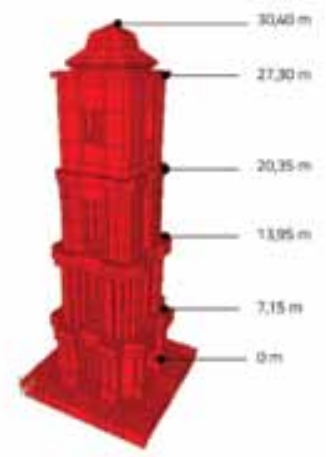

Figure 7. Specific points on the model

of both earthquake recordings is also taken into account in the analyses. As shown in Figure 5, the peak acceleration takes place at $25 \mathrm{sec}$. for the soft soil, and at $50 \mathrm{sec}$. for the stiff soil. Earthquake waves propagate faster in stiff soil when compared to soft soil. It can also be noted that the soft soil magnifies earthquake accelerations about 3 times more than those of the stiff soil.

Specific points at $0 \mathrm{~m}, 7.15 \mathrm{~m}, 13.95 \mathrm{~m}, 20.35 \mathrm{~m}, 27.30 \mathrm{~m}$ and 30.4 from the marble platform datum are investigated to compare relative displacements of the tower (Figure 7). The comparison of tower displacements depending on soil conditions is shown in Figure 8.

As can be seen in Figure 8a, relative displacements increase with the height for both soil conditions. Numerical values of relative displacements $\left(U_{x}\right)$ at critical points in the $x$ direction are determined as $2 \mathrm{~cm}, 11.6 \mathrm{~cm}, 24.7 \mathrm{~cm}, 37.4 \mathrm{~cm}, 50.8 \mathrm{~cm}$, and $56 \mathrm{~cm} ; 1.3 \mathrm{~cm}, 7.7 \mathrm{~cm}$, $16.4 \mathrm{~cm}, 24 \mathrm{~cm}, 33 \mathrm{~cm}$ and $37 \mathrm{~cm}$, respectively, for recordings made in the soft and stiff soil conditions. Similarly, relative displacements in the $U_{y}$ direction increase drastically as the recordings change from the stiff to soft soil (Figure $8 \mathrm{~b})$. If relative displacements are compared at the top of the tower, displacements increase by $51 \%$ in $U_{x}$ direction and by $78 \%$ in $U_{y}$ direction for the Fatih recording.

After having defined the deformed shape of the clock tower under earthquake ground motions recorded at different soil conditions, internal forces and stresses are also determined. This point is an important aspectfor the repair and strengthening of historical buildings. It is well known that structural stresses increase when earthquake forces are considered in addition to the self-weight of the structure. While Figure 3 shows stress contours of the tower under its self-weight, Figure 8 shows stress contours under earthquake ground motions recorded in different soil conditions. In these figures, four points, i.e. $A, B, C$, and $D$, are selected to observe stress values obtained from the analysis. While point $A$, with the height of $13.95 \mathrm{~m}$ from the base, is located at the window opening on the second floor, the point $B$, with the height of $7.15 \mathrm{~m}$ from the base, is located at the first floor window opening. The point $C$ is at the contact between the marble base and superstructure. Finally, the Point $D$, with the height of $7.15 \mathrm{~m}$, is in the middle of the first floor.

Under earthquake loads, stresses at Point A, Point B, Point C, and Point $D$ increase about 23, 5, 2, 14 times for BR recording, 

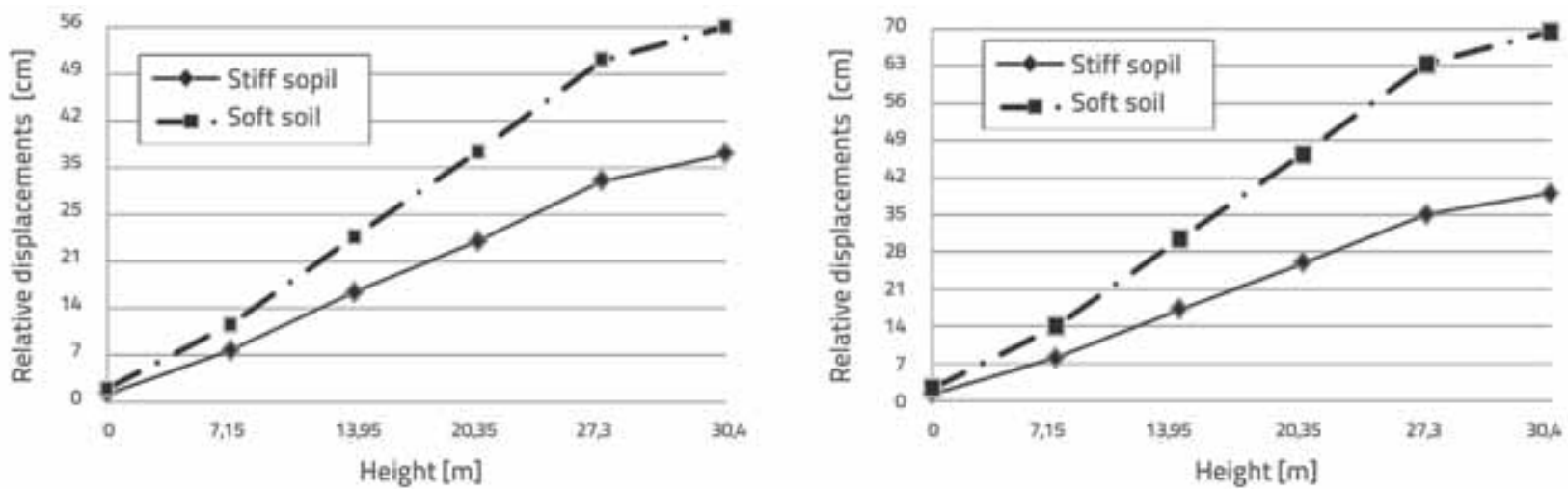

Figure 8. Relative displacements of clock tower: a) at Ux direction; b) at Uy direction
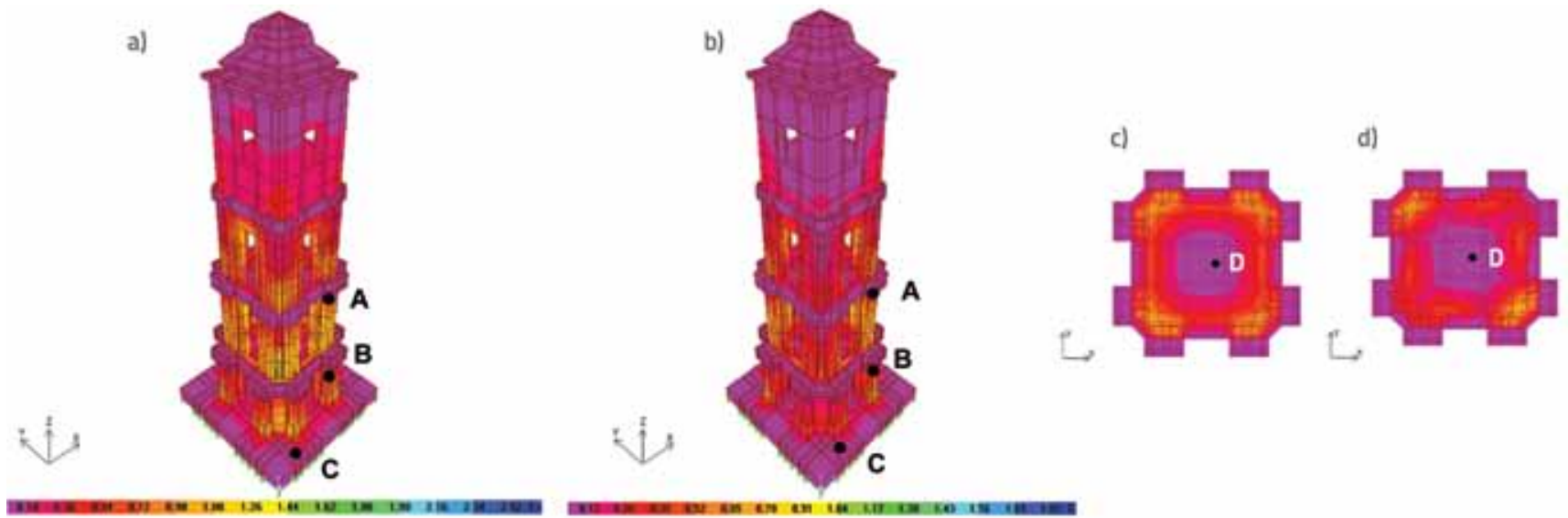

Figure 9. Stress contours of clock tower: a) in soft soil; b) in stiff soil; Stress contours at the first floor slab: c) in soft soil; d) in stiff soil

Table 4. Stress values of Dolmabahce clock tower for Kocaeli earthquakes records

\begin{tabular}{|c|c|c|c|c|}
\hline Observed conditions & $\begin{array}{c}\text { Stress values in } \\
\text { point A [MPa] }\end{array}$ & $\begin{array}{c}\text { Stress values in } \\
\text { point B [MPa] }\end{array}$ & $\begin{array}{c}\text { Stress values in } \\
\text { point C [MPa] }\end{array}$ & $\begin{array}{c}\text { Stress values in } \\
\text { point D [MPa] }\end{array}$ \\
\hline Dead load & 0.006 & 0.050 & 0.155 & 0.001 \\
\hline Soft soil & 0.266 & 0.505 & 0.627 & 0.047 \\
\hline Stiff soil & 0.166 & 0.256 & 0.286 & 0.028 \\
\hline
\end{tabular}

respectively and 38, 10,4 and 23 times for $F R$ recording, respectively, when they are compared with those of the self-weight responses (Table 4). If the stress distribution is examined specifically for earthquake loads, stress accumulations are observed, and these stresses increase considerably at the points close to the base plate contacts and around the hollows of the building. It can be noticed that some damage and cracks may occur in these regions of the clock tower under earthquake motions.

Stresses of solid elements in the model at Points $A, B, C$, and D increase by about 1.6, 1.9, 2.3 and 1.7 times, respectively, for soft soil, when compared with stress values for stiff soil. Maximum stresses occur at the fixed joint between the structure and marble base plate, and the stresses decrease over the height of the tower. This result supports the results of the study performed by Dogliani and Motti. In that study it was stated that "damage caused by the 1976 Friuli earthquake shows that damage patterns on isolated bell towers tend to be distributed along the height, although damage is frequently more severe near the base [30]".

\section{Conclusions}

Effects of two earthquake recordings of the same earthquake motion, recorded in different soil conditions, on the structural behaviour of a historical masonry clock tower, considering the sub-soil in the foundation, are investigated in this study. Damage to historical structures due to earthquake action depends on many parameters, site conditions being among the most important ones. As much as soil affects seismic waves which propagate in it, seismic waves can also affect the strength and deformation properties of soil. Therefore, to understand the dynamic behaviour of the clock tower, the soil-structure interaction (SSI) is taken into account in this study with the Winkler's method. The following conclusions can be drawn from the study:

- Since the stresses caused solely by the weight of the structure are within allowable stress limits for masonry structures, they should not put in danger the overall stability of the structure.

- Earthquake forces and relative displacements at the floors clearly increase for the earthquake ground motion recorded 
in soft soil. Relative displacements and stresses for solid elements increase up to 1.5 and 2 times, respectively, under the earthquake motion recorded in soft soil. These results reveal the importance of variable characteristics of earthquake ground motions depending on the soil type on which the structure is constructed, especially for historical structures.

- It can be seen from static and dynamic analyses of the model that stresses accumulate especially at the base plate and at the hollows of the tower. Therefore, the most severe

\section{REFERENCES}

[1] Binda, L., Gatti, G., Mangano, G., Poggi, C., Sacchi Landriani. G.: The collapse of the Civic Tower of Pavia: a survey of the materials and structure. Masonry International; 6(1): 11-20, 1992.

[2] Binda, L., Anzani, A., Mirabella Roberti, G.: The failure of ancient towers; problems for their safety assessment Proceedings o the 4th International Conference on Structural Studies, Repairs and Maintenance of Heritage Architecture, China,179-186, 1995.

[3] Calvi, G.M., Priestley, M.J.N.: Post collapse analyses of a medieval masonry tower. 5th North American Masonry Conference, University of Illinois at Urbana Champaign, USA, 3-6, 1990.

[4] Binda, L., Tongini Folli, R., Mirabella R.G.: Survey and investigations for the diagnosis of damage in masonry structures: the "Torrazzo" of Cremona. Proceedings of the 12th International brick/block Masonry Conference, Spain, 237-257, 2000.

[5] Valluzzi, M.R., Da Porto, F., Modena, C.: Structural investigation and strengthening of the Civic Tower in Vicenza. Proceedings of Structural Faults Repairs, United Kingdom, 10-22, 2003.

[6] Lionello, A., Cavaggioni, I., Modeno, C., Casarin, F., Rossi, P.P., Rossi, C.: Experimental and numerical analysis of the structural behavior of St Stefano's bell tower in Venice Proceedings of the 4th International seminar on structural analysis of Historical constructions, Italy. 533-542, 2004.

[7] Carpinteri, A., Invernizzi, S., Lacidogna, G.: In situ damage assessment and nonlinear modelling of a historical masonry tower. Engineering Structures, vol. 27, 387-395, 2005.

[8] Cansever, M.: Türkiye'nin Kültür Mirası: 100 Saat Kulesi. İstanbul. NTV Press, 2009.

[9] Specification for Structures to be Built in Disaster Areas, Ministry of Public Works and Settlement Government of Republic of Turkey, 2007.

[10] Soyluk, A., Harmankaya, Z.Y.: Deprem Bölgelerine Göre Saat Kuleleri, Safranbolu Saat Kulesi Ve Zaman Ölcerler Sempozyumu, Safranbolu, 2010

[11] Korkmaz, H.: The Relationship Between Ground Conditions And Earthquake Effect In Antakya, Coğrafi Bilimler Dergisi, 4 (2), 4966,2006

[12] Lutes L.D, Shahram S., Shuang J.: "Response Variability of SSI system with uncertain structural and soil properties" Engineering Structures, Vol 22, pg 605-620, 2000

[13] Ozmen, C., Er Akan, A., Unay, A.I.: Analysis of a historic masonary building, GRAĐEVINAR 63 (2011) 5, 449-458.

[14] Toker, S., Ünay A. I.:Mathematical Modeling and Finite Element Analysis Of Masonry Arch Bridges Gazi University Journal of Science 17(2). 129-139, 2004

[15] Cook, R. D.: Concept and Applications of Finite Element Method as Used the Analysis of Displacement, Strain and Stress, John Wiley and Sons Inc, New York, 1974 damage should occur in these regions under earthquake loads.

It can therefore be concluded that different recordings of a single earthquake made in different soil conditions will have different effects on the same historical structure. On the other hand, without knowing the soil conditions, it would be very illusory to define these effects. These results clearly imply that the fixed base assumption will not be realistic for the dynamic analysis of structural systems.

[16] Gezgör, V.: Dolmabahce Saat Kulesi, Milli Saraylar Dergisi, vol I. 124-128, 1997

[17] Italia Ice, (2010) Dolmabahce Saray Saat Kulesinin Konservasyonu: İnceleme Projesinden Santiye Okuluna, Italyan Ticaret Merkezi, Istanbul.

[18] Artar, M.: Structural identification of the Sehzade Mehmet Mosque through static and dynamic analyses, MSc. Thesis, Boğazici University, İstanbul, 2006

[19] Kaya, S.M., Aydınoglu, M.N., Erdik, M., Yüzügüllü, Ö.: Determination of Dynamic Characteristics of Suleymaniye Mosque by Analytical and Experimental Methods, Compatible Materials for the Protection of European Cultural Heritage Pact, Istanbul, 56-68, 1998

[20] Erguvanlı, K., Ahunbay, Z.: Mimar Sinan İstanbul'daki Eserlerinde Kullandığı Tașların Mühendislik Jeolojisi ve Mimarlık Özellikleri, Mühendislik Jeolojisi Bülteni, İstanbul, 11-12, 1989.

[21] Cili, F., Sesigur, H., Celik, O.C.: "Survey-Restitution-Restoration Project of Dolmabahce Mosque in Beyoglu District, in the City of Istanbul; Technical Report" Istanbul Technical University Working Capital Managements, Project No Mi-2006-10, Istanbul, 2005. (In Turkish).

[22] Bezgin, Ö.: "An Insight Into The Theoretical Background Of: Soil Structure Interaction Analysis Of Deep Foundations" istanbul, (http://www.ymprefab.com.tr/download/), 2010.

[23] Dowrick, D. J.: "Earthquake Resistant Design for Engineers and Architects" , 2nd Ed, John Wiley and Sons, New York, 1992.

[24] Sap2000, Integrated Structural Analysis and Design Software, Computers and Structures, Inc., Berkeley, California.

[25] Gavrilovic, P., Kelly, S.J. Sendova, V.: Seismic Protection of Byzantine Churches, Apt Bulletin, Vol.34, 63-69, 2003.

[26] Mehta, D., Gandhi, N. J.: Time Response Study of Tall Chimneys, Under the Effect of Soil Structure Interaction And Long Period Earthquake Impulse, The 14th World Conference On Earthquake Engineering ( http://www.iitk.ac.in/nicee/wcee/article/14_ S10-045.pdf ), 2008

[27] Ilerisoy, Z.Y, Soyluk, A.: Impact of shallow earthquakes on the Sehzade Mehmet Mosque, GRAĐEVINAR 64 (2012) 9, 735-740.

[28] NISEE, Pacific Earthquake Engineering Research Center, University of California, CA (http://nisee.berkeley.edu/turkey/ Fturkch1.pdf), 2011

[29] Peer Ground Motion Database, Pacific Earthquake Engineering Research Center, University of California, CA (http://peer. berkeley.edu/peer_ground_motion_database/spectras/1/ unscaled_searches/ 1537/edit), 2011.

[30] Doglioni, F., Moretti, A., Petrini, V.: (eds), Le Chiese e il Terremoto (in Italian), Lint Press, Trieste, 1994 